\title{
Demistifikasi Tokoh Don Juan dalam La Nuit De Valognes Karya Eric-Emmanuel Schmitt ${ }^{1}$
}

\author{
Talha Bachmid dan S. Riella R Muridan
}

\begin{abstract}
Don Juan is a myth about a seducer, a man with many love adventures, a women's heat conqueror, and many other predicates. Don Juan as a myth is well-known world wide over, appearing in about 50 writings such as novels, plays, operas. But a French writer Eric-Emannuel Schmitt proposes a new figure of Don Juan in his play La Nuit de Valognes (Night in Valognes): the seducer is judged by five victims and convicted to marry one of his victims in order to stop his adventures. Surprisingly, Don Juan accepts this verdict without conditions. This sudden change becomes the theme of the play: the demythification of Don Juan. A flash back scene shows the beginning of this change and the interpretations that might arise from here. One possible interpretation is proposed and discussed in this paper: Don Juan found the way to a purer love, which is the union with God, and decides to begin his journey. This play can thus be categorised as a sufi text.
\end{abstract}

KEYWORDS new figure of Don Juan, demythification, sufi text

Tokoh Don Juan atau Dom Juan yang terkenal di dunia sebagai pria perayu telah menghidupi puluhan karya sastra ataupun seni di Eropa sejak Abad Pertengahan. Berawal dari sebuah legenda di Spanyol, sosok ini kemudian diambil sebagai tokoh oleh banyak pengarang dan menjadi sebuah mitos. Hingga akhir abad ke-20, tercatat lebih dari 50 karya sastra dan seni dari Inggris, Jerman, Italia, Spanyol yang mengangkat sosok ini, termasuk di antaranya para sastrawan Prancis, yaitu Molière, Prosper Mérimée, Alexander Dumas, dan Edmond Rostand. Salah satu pengarang Prancis yang terkenal saat ini, yaitu Eric-Emmanuel Schmitt, juga mengambil Don Juan sebagai tokoh utama dalam lakonnya yang berjudul La Nuit de Valognes, pertama kali dipentaskan pada tahun 1991. La Nuit de Valognes, adalah karya pertamanya yang berbentuk teater dan langsung mendapat tanggapan sangat positif dari publik Prancis. Karya ini berkisah tentang "pengadilan" tokoh Don Juan oleh lima perempuan Prancis mantan korbannya. Namun, kelima perempuan yang sudah siap dengan dakwaan dan hukuman tersebut ternyata harus kecewa

Pernah disajikan sebagai makalah Seminar Gelar Sastra Dunia, 19-20 Juli 2005, Fakultas Ilmu Pengetahuan Budaya Universitas Indonesia, Depok. 
karena Don Juan yang mereka temui bukanlah Don Juan yang selama ini mereka kenal. Don Juan telah berubah. Apa saja perubahan yang terjadi pada Don Juan, dan bagaimana perubahan itu terjadi? Beberapa sutradara yang mementaskan karya Schmitt menyatakan bahwa dalam La Nuit de Valognes ini, Schmitt telah mengubah mitos Don Juan Sang Perayu, menjadi Don Juan yang berbeda. Masalah perubahan mitos inilah yang akan dibahas dalam tulisan ini. Mula-mula akan diteliti kekhasan karya Schmitt dalam mengungkapkan tokoh pria perayu itu, kemudian akan dipaparkan demistifikasi tokoh yang terjadi.

\section{ERIC-EMMANUEL SCHMITT}

Pengarang ini lahir pada 28 Maret 1960 di pinggiran kota Lyon. Seorang doktor filsafat lulusan sekolah elite Ecole Normale Supérieure yang rela meninggalkan pekerjaannya sebagai dosen filsafat di Universitas Savoy untuk sepenuhnya menggeluti bidang sastra. Karya-karyanya telah diterjemahkan dalam 35 bahasa dan beberapa lakonnya telah dipentaskan di sekitar 40 negara. Setelah La Nuit de Valognes, karya teater kedua Schmitt, Le Visiteur, pada tahun 1994 memperoleh penghargaan 3 Molière ${ }^{2}$, termasuk di antaranya untuk pertunjukan terbaik dan penulis terbaik. Schmitt juga menulis monolog, roman, esai, dan skenario film yang mengangkat beragam tema. Latar belakang filsafat yang didalami sebelumnya memberi warna yang khas pada setiap karyanya, terutama sikap kritisnya terhadap segala sesuatu yang sudah menjadi doksa atau sesuatu yang sudah diterima, yang kadang sudah tidak dipertanyakan lagi kebenarannya, seperti mitos, ideologi, dan agama. Selain menghasilkan beragam karya yang bermutu dan mendapat berbagai penghargaan, Schmitt juga bekerja sama dengan berbagai institusi terkemuka dan banyak tokoh terbaik di dunia sastra dan seni. Oleh karena itu, tidaklah mengherankan apabila Eric-Emmanuel Schmitt menjadi penulis yang paling banyak dibicarakan publik Prancis saat ini dan telah menjadi bagian dari sastra dunia kontemporer.

\section{RINGKASAN CERITA}

Secara ringkas, lakon la Nuit de Valognes mengisahkan upaya tokoh, seorang perempuan bangsawan Prancis, yaitu Duchesse de Vaubricourt yang pernah dikecewakan oleh Don Juan, untuk mengumpulkan empat korban Don Juan lainnya yang berasal dari lingkungan sosial berbeda untuk mengadili Don Juan. Empat perempuan Prancis lain adalah Comtesse de la Roche-Piquet, perempuan bangsawan dengan kehidupan gemerlapan serta memiliki banyak kekasih; Hortense de Hauteclair atau La Religieuse, biarawati; Mademoiselle de la Tringle, penulis novel ber-genre love stories; dan Madame Cassin, ibu rumah tangga dari kelas sosial menengah. Gagasan untuk mengadili Don Juan yang datang dari nyonya rumah puri di desa Valognes itu ditanggapi dengan sungguh-sungguh oleh keempat tamunya. Mereka akan menghukum

$2 \quad$ Molière adalah dramawan Prancis abad ke-17 yang namanya diabadikan sebagai nama penghargaan tertinggi untuk dunia teater di Prancis. 
Don Juan dengan memaksa tokoh perayu itu untuk "bertobat" dan menikahi anak baptis Duchesse, yaitu Angélique, yang merupakan korban terakhir Don Juan. Apabila Don Juan menolak, Duchesse yang memiliki hubungan dekat dengan kalangan istana telah berhasil mendapatkan surat perintah dari Raja untuk memenjarakan Don Juan atas semua kesalahannya pada masa lalu.

Kejutan pertama muncul ketika Don Juan tanpa ragu menerima vonis itu. Mula-mula kelima perempuan itu cukup senang, tetapi setelah pemilik puri mendengarkan percakapan Don Juan dengan Angélique tanpa sepengetahuan mereka, rencana awal dibatalkan. Duchesse meragukan keaslian Don Juan; tidak mungkin pria perayu itu sudah berubah begitu drastis. Diperlukan kesaksian seorang tokoh lain untuk membuktikan bahwa Don Juan yang datang itu asli. Sganarelle, tokoh pembantu Don Juan datang dan menegaskan bahwa majikannya memang Don Juan asli.

Tuduhan Duchesse bukan tanpa alasan, dia memegang buku catatan Sganarelle yang memuat nama para perempuan korban Don Juan, dilengkapi dengan tanggal kejadiannya. Duchesse melihat bahwa sejak lima bulan yang lalu, buku catatan itu kosong; apa yang terjadi sejak saat itu? Sganarelle berusaha menjawabnya dan kita dibawa ke masa lalu, tepatnya lima bulan 28 hari yang lalu.

Kilas balik berupa adegan perjalanan Don Juan dan Sganarelle di Desa Valognes. Ketika mereka melewati kuburan, salah satu patung yang umumnya menghiasi kuburan bergerak, ternyata seorang anak muda yang kemudian diketahui bernama Chevalier de Chiffreville. Pemuda ini mengajak Don Juan minum di sebuah kafe dan ternyata Don Juan menemukan kenyataan yang mengejutkan dirinya sendiri. Ia menunggu terus kehadiran pemuda itu, padahal Don Juan pernah menyakiti Angélique, adik pemuda itu. Pada akhir kisah mereka, dalam duel, Chevalier dengan sengaja menikamkan dirinya ke pedang Don Juan dan menemui kematian. Sebelum meninggal, ia sempat mengakui bahwa ia lah cinta yang dicari Don Juan selama ini dan tidak pernah ditemukan. Di akhir adegan, Don Juan digambarkan memangku tubuh Chevalier, dan dibandingkan dengan "pieta" atau tokoh Maria yang merasakan kesengsaraan putranya.

Kembali ke latar kini, kisah Sganarelle membawa reaksi berbeda dari kelima perempuan. Biarawati, penulis novel, Angélique, dan Comtesse pergi meninggalkan Don Juan dengan perasaan kecewa. Ajakan Don Juan untuk menikahi Angélique ditolak. Hanya pemilik puri dan ibu rumah tangga yang memahami Don Juan. Lakon ini diakhiri dengan kepergian Don Juan sebagai seorang yang "lahir kembali". Kelahiran kembali Don Juan dilambangkan dengan kedatangan fajar.

\section{PENOKOHAN DON JUAN}

Dari ringkasan cerita di atas, terlihat beberapa perubahan bila dibandingkan dengan lakon tentang Don Juan yang ditulis sebelum ini. Kami hanya akan merujuk pada sebuah karya yang dapat mewakili lakon sebelumnya, yaitu 
Dom Juan ou le Festin de Pierre, karya Molière, dari abad ke-17.

Di dalam lakon Molière, Don Juan yang melarikan diri dari kejaran saudara-saudara iparnya, sempat menipu dan merayu beberapa perempuan lain. Sosok Don Juan di dalam lakon Schmitt, pada awalnya, masih memperlihatkan sifat yang sama, yaitu sinisme menghadapi perempuan. Caranya menanggapi atau menjawab pertanyaan kelima perempuan yang akan mengadilinya itu menunjukkan bahwa perempuan di matanya masih merupakan makhluk lemah. Penulis novel misalnya, yang sejak kedatangannya menyangkal mengenal Don Juan, akhirnya menyerah setelah pria perayu itu dengan lancar menuturkan kisah cinta mereka. Tokoh perempuan di dalam lakon Schmitt ditampilkan sebagai kumpulan pribadi yang kompleks, yang sulit mendamaikan dualisme dalam diri mereka ketika harus menghadapi Don Juan. Di satu sisi mereka ditampilkan sebagai sosok yang menyimpan dendam, agresif, dan sangat bersemangat untuk mengadili dan menjatuhkan hukuman pada Sang Perayu. Mereka mempersiapkan diri dengan sungguh-sungguh agar tidak lagi terjebak dan termakan rayuan manis yang pasti akan membanjiri mereka. Di sisi lain, para korban rayuan Don Juan ini masih memperlihatkan sikap yang sama, yaitu tetap memuja pria perayu itu. Kesamaan mereka terlihat, misalnya, dari cara mereka mengisahkan pengalaman bersama Don Juan dengan nada nostalgis, penuh sentimentalisme dan keluguan, yang terdengar seperti kisah usang dalam cerita cinta picisan.

Dilihat dari kesamaan ciri-ciri tokoh wanita yang ditampilkan, mereka dapat saling menggantikan. Mereka merupakan metonimi dari kelemahan sendiri. Seperti yang dikatakan oleh Anne Ubersfeld dalam karyanya Lire le théâtre (1978:182), tokoh sebagai satuan leksikal, juga memiliki makna kiasan, yaitu metonimi dan metafora. Setiap tokoh perempuan dalam lakon ini mewakili kelompok perempuan berbeda, seperti biarawati yang menjadi metonimi perempuan terkurung sekaligus mewakili perempuan religius; penulis novel dan Angelique mewakili perempuan intelektual yang terlalu memuja cinta, dan perempuan bangsawan mewakili kalangan atas dengan beragam norma dan nilai sosial yang menyertainya, serta ibu rumah tangga yang mewakili perempuan yang sangat percaya pada kesetiaan.

Kembali mengacu pada cerita Molière, Don Juan dalam perjalanannya bersama Sganarelle, pada suatu saat, melewati kuburan dan melihat patung tokoh Commandeur, ayah perempuan yang pernah dikecewakan oleh Don Juan, dan yang dibunuh oleh Don Juan dalam duel. Sganarelle berusaha menakut-nakuti majikannya, tetapi dengan nada menantang Dom Juan menyuruh pelayannya mengundang patung itu makan malam bersama mereka. Tanpa disangka, patung menganggukkan kepalanya, datang ke rumah Don Juan untuk makan malam, dan kemudian balik mengundangnya. Pada pertemuan mereka yang kedua, patung memegang tangan Don Juan dan pada saat itu petir menyambar dan bumi menelan pria perayu itu.

Pada versi Schmitt, patung batu juga dimunculkan kembali dalam wujud Chevalier de Chiffreville. Di dalam lakon Molière, patung Commandeur hidup 
kembali untuk menghukum Don Juan; dan Schmitt menggunakan unsur sama yaitu patung yang hidup kembali untuk menghukum Don Juan. Patung dalam kedua lakon adalah metonimi kekuasaan ilahi. Namun, perbedaan sangat besar muncul di dalam lakon Schmitt. Penghukum Don Juan adalah Chevalier, yang berwujud seorang pemuda, dan hukuman yang jatuh juga tidak berupa kematian Don Juan, tetapi kematian Chevalier. Pemuda yang mengaku mencintai Don Juan tanpa pamrih mengatakan bahwa mereka berdua dihukum; Don Juan dihukum karena tidak mampu menginginkan dan mendapatkan cinta seperti yang ditawarkan kepadanya (cinta pemuda itu); sedangkan pemuda itu juga tidak mungkin mencintai Don Juan. Namun, keduanya sepakat bahwa cinta itu berada di dalam diri mereka, dan cinta mereka identik dengan Tuhan sekaligus menjadi bukti keberadaan Tuhan. Dari dialog antara Don Juan dan Chevalier de Chiffreville, dapat pula dikatakan bahwa pemuda itu merupakan metonimi dari Don Juan, bagian dari dirinya yang mewujud dan yang kemudian terbunuh atau harus dikorbankan.

Selain tokoh, benda juga memiliki fungsi metonimis dalam lakon ini. Salah satu tokoh dan benda yang sangat penting adalah Sganarelle sang pelayan dan buku catatannya. Buku catatan adalah metonimi masa lalu Don Juan; catatan di buku berhenti pada saat tertentu sehingga terdapat kekosongan, dan ini merupakan tanda perubahan. Sganarelle mewakili masa lalu sekaligus jembatan dengan masa kini ketika ia menceritakan kilas balik kejadian penting yang mengubah Don Juan untuk selamanya. Dibandingkan dengan lakon Molière, perbedaan terbesar terlihat melalui adegan kilas balik itu. Jelas bahwa Don Juan sudah berubah. Bagaimana menyikapi perubahan tersebut, dan bagaimana mengungkapkan makna metaforis tokoh Don Juan ini?

\section{DEMISTIFIKASI}

Di dalam La Nuit de Valognes tampak ada usaha untuk membongkar mitos yang selama ini melekat pada diri Don Juan, seperti tokoh perayu, seorang libertin yang memuja kebebasan, dan seorang ateis.

Sang Perayu adalah Don Juan. Catatan Sganarelle, sang pendamping setia Don Juan, menjadi saksi tak terbantahkan atas reputasinya sebagai perayu andal. Tersebutlah 640 perempuan Italia, 231 perempuan Jerman, 100 perempuan Prancis, 91 perempuan Turki, dan 1003 perempuan Spanyol, korban rayuan Don Juan! Mitos Sang Perayu ini dibangun dari penokohan Don Juan sebagai sosok yang tampan, menarik, pandai berbicara, dan paham berbagai cara menyenangkan dan menaklukkan hati perempuan. Rangkaian kata yang indah dan memabukkan banyak hati dan pikiran perempuan, begitu mudah keluar dari mulutnya, seperti "Mata terindah yang pernah ada"; "Bibir termanis"; atau "Tangan-tangan yang paling mungil...". Setiap perempuan yang berhadapan dengan rayuan Don Juan akan terpesona dan segera takluk dalam pelukannya. Malangnya, setelah ditaklukkan, mereka akan ditinggalkan. Don Juan tidak pernah bertahan lama dengan satu perempuan. Pada saat perempuan telah masuk ke dalam perangkapnya, selesai sudah perburuannya. Ia akan segera meninggalkan perempuan itu untuk mencari 
korban berikutnya. Hal itu berlangsung terus-menerus hingga muncullah deretan perempuan berbagai bangsa seperti dalam catatan Sganarelle.

Tokoh Don Juan sebagai perayu perempuan tidak lagi muncul dalam karya Schmitt. Don Juan versi Schmitt ditampilkan sebagai laki-laki yang murung, dingin, tidak memiliki hasrat yang menggebu-gebu lagi untuk merayu atau menaklukkan perempuan. Hal ini tampak dalam adegan akhir Babak I, dalam dialog antara Duchesse dan pelayan perempuannya, Marion.

Duchesse: "Jawab pertanyaanku. Jangan takut. Aku ingin tahu kejadian yang sesungguhnya. Saat kau meminta Don Juan untuk menunggu, apakah ia menebar pesona? Apakah ia mencoba merayumu?

Marion: Tidak, Madame. Ia hanya duduk di sudut yang paling gelap dan menunggu dengan tenang.

Duchesse: Baik. Tapi,.. apakah ia tidak melontarkan kata, gerakan, atau pandangan yang....

Marion: Tidak, Madame.

$(\ldots \ldots)$

Duchesse: Dan dia tidak memberimu sesuatu, atau menjanjikan sesuatu?

Marion: Tidak, madame.

Duchesse: Aneh! Semuanya aneh! Sangat aneh!

Pada awalnya Don Juan masih mencoba berpura-pura tampil "normal", sebagai Sang Perayu seperti yang dibayangkan para perempuan yang mengadilinya. Namun, Sganarelle mengetahui hal itu dan mendesak majikannya untuk mengakhiri sandiwaranya. Sebaliknya, para perempuan dalam lakon ini ditampilkan secara berbeda pula. Mitos perempuan sebagai korban yang tidak berdaya, "binatang buruan", atau "barang mainan" tidak lagi ditonjolkan. Kelima perempuan, termasuk Angélique, sejak awal telah mempersiapkan diri dengan baik untuk menghadapi orang yang telah merayu dan memperdaya mereka. Mereka bahkan cenderung agresif dan tidak memberi kesempatan kepada Don Juan untuk membela diri. Dendam dan sakit hati membuat mereka bersumpah untuk menghukum Don Juan seberatberatnya. Hal yang menarik adalah para perempuan itu sebenarnya di dalam sudut hatinya masih memuja Don Juan. Ketika mereka sadar bahwa Don Juan yang berdiri di hadapan mereka telah berubah, reaksi mereka berbeda-beda, ada yang menerima ada juga yang kecewa.

Don Juan adalah seorang libertin. Libertin atau pemuja kebebasan di sini memiliki dua makna, yaitu pertama sebagai pemuja kebebasan fisik yang mengejar kepuasan jasmani atau lebih khusus lagi kepuasan seksual. Merayu dan menjalin hubungan dengan perempuan, untuk kemudian ditinggalkan 
dan mengejar perempuan lain adalah kenikmatannya. Makna libertin yang kedua, yaitu pemuja kebebasan berpikir. Keragaman latar belakang perempuan yang ditaklukkan Don Juan telah dibahas sebelumnya sebagai metonimi dari religiusitas, pemuja cinta, percaya pada kesetiaan, dan norma sosial. Kelimanya menegaskan hal-hal atau nilai-nilai yang ditentang oleh Don Juan. Inilah sisi yang paling menarik dari figur Don Juan, yang membuatnya menjadi tokoh yang selalu dihadirkan kembali oleh para sastrawan dan seniman sepanjang zaman. Kebebasan berpikir yang ada di dalam dirinya menjadi sarana bagi setiap pengarang atau seniman untuk mengembangkan gagasan mereka. Hal yang menarik di dalam karya Schmitt ini adalah ide kebebasan tidak lagi keluar dari mulut Don Juan. Misalnya ide tentang cinta sejati yang diungkapkan oleh Mademoiselle de la Tringle, penulis novel. Ketika menyadari perubahan Don Juan dia bertanya apakah sekarang Don Juan akan mencintai perempuan dan percaya pada cinta yang abadi dan absolut seperti di dalam novel-novelnya. Dan ketika Don Juan menjawab, "Ya", perempuan ini kecewa. Ia memaki Don Juan sebagai laki-laki tolol yang percaya pada novel-novelnya yang bodoh. Justru perempuan inilah yang menegaskan bahwa tidak ada cinta yang sejati.

Demikian juga kritik terhadap Tuhan yang selama ini ditentang Don Juan, justru dilontarkan oleh Sang Biarawati yang juga kecewa karena Don Juan telah berubah. Sang Biarawati menumpahkan kekecewaannya dengan memaki-maki "Tuhan" sebagai sosok "Laki-laki" yang telah menjadikannya "pengantin", ternyata juga tidak lebih baik daripada Don Juan. Kesetiaan dan pengabdian yang ia persembahkan ternyata dibalas "Tuhan" dengan "pengkhianatan" juga karena Tuhan tidak pernah menjawab doa-doa dan permohonannya. Bahkan, ketika akhirnya ia mendapat kesempatan untuk membalas sakit hatinya pada Don Juan yang pernah menipunya, Tuhan "mengkhianatinya" dengan mendatangkan Don Juan yang telah berubah. Tuhan yang ia puja ternyata Tuhan yang "bisu", yang tidak pernah "hadir", dan yang hanya menikmati berbagai siksaan batin yang diderita oleh para biarawati sepanjang hidupnya.

Lalu apa sebenarnya yang berubah pada Don Juan?

"Tout le plaisir de l'amour est dans le changement" (Seluruh kenikmatan cinta ada dalam perubahan). Kenikmatan cinta akan hilang ketika semuanya mencapai stabilitas atau kemapanan karena stabilitas berarti berhenti, dan berhenti berarti mati. Di dalam karya Molière, juga dalam karya tentang Don Juan yang lain, le plaisir atau kenikmatan adalah sesuatu yang selama ini dicari dan dipuja oleh Don Juan. Ia mendapatkan kenikmatan itu ketika berusaha merayu para perempuan dan berhasil menaklukkannya, untuk kemudian meninggalkannya. Ia tidak mampu dan tidak ingin bertahan lama-lama pada satu perempuan karena kenikmatan itu akan hilang ketika perempuan itu telah tunduk padanya.

Perbedaan Don Juan versi Schmitt adalah dalam memaknai kata perubahan itu. Yang inti adalah perubahan itu sendiri, bukan kenikmatan yang dicari. Pertemuannya dengan Chevalier menumbuhkan perasaan baru 
yang selama ini tidak pernah ia rasakan ketika bersama para perempuan. Ia selalu merindukan kehadiran Chevalier kembali dan dengan setia menanti kedatangannya. Ia bahkan menunjukkan rasa cemburu ketika mengetahui bahwa Chevalier tidak datang karena menemui Fiammetta, pelacur paling terkenal di daerah itu. Apakah berarti Don Juan jatuh cinta pada sesama pria? Don Juan versi Schmitt seorang homoseksual? Mungkin saja. Schmitt sendiri dalam situs resminya mengutip pernyataan beberapa psikolog yang menyatakan bahwa salah satu tanda homoseksualitas adalah ketika seorang laki-laki terus berganti-ganti perempuan dan tidak pernah menemukan kenikmatan yang sesungguhnya, sebelum kemudian ia temukan pada diri sesama laki-laki (http//www.eric-emmanuel Schmitt.com, 28 Juni 2005). Namun, Schmitt tidak ingin membahas hal itu lebih jauh dan menyerahkan interpretasi sepenuhnya pada pembaca.

Ada hal lain yang ingin kami angkat lebih tinggi, yaitu Don Juan yang berubah. Adegan Don Juan menggendong mayat Chevalier disejajarkan dengan gambaran pièta, Maria yang memangku tubuh Jesus. Apabila Jesus mati untuk sebuah pengorbanan, menebus dosa para umatnya, Don Juan juga percaya bahwa Chevalier mati untuk sebuah pengorbanan. Namun, pengorbanan untuk apa? Sebuah pengorbanan untuk perubahan, yaitu perubahan dirinya sendiri. Kejenuhan yang ia alami ketika berhadapan dengan para perempuan menunjukkan stagnasi di dalam dirinya. Jika Don Juan, sebelumnya, memaknai perubahan sebagai perubahan pasangan, alias berganti-ganti perempuan, Don Juan versi Schmitt sadar bahwa merayu perempuan, menjatuhkan perempuan dalam pelukannya, dan kemudian meninggalkannya, telah menjadi satu pola tetap yang justru menjebaknya dalam sebuah rutinitas petualangan cinta. Stagnasi itu ada di dalam dirinya, maka dirinyalah yang harus berubah. Berubah menjadi apa? Menjadi siapa? Don Juan sendiri tidak tahu. Schmitt mengibaratkan perubahan sebagai kelahiran kembali untuk menjalani sebuah perjalanan panjang. Don Juan versi Schmitt tetap Don Juan yang memuja kebebasan, tetapi kebebasan untuk berubah menjadi pribadi lain yang berbeda dari sebelumnya.

Kelahiran kembali Don Juan untuk menjalani sebuah perjalanan panjang, apabila dikaitkan dengan ide cinta dan Tuhan, memperlihatkan ide sufisme yang ingin diangkat oleh Schmitt. Sebagai seseorang dengan latar belakang filsafat, Schmitt dikenal tertarik pada ide sufisme ini, yang kemudian akan ia kembangkan dalam karya-karya berikutnya.

Adegan Don Juan yang merindukan Chevalier layaknya merindukan seorang kekasih, mengingatkan kita pada kisah tokoh sufi Jalaluddin Rumi yang selalu merasa rindu dan selalu ingin dekat dengan Salahuddin Faridun Zarkub atau sebelumnya dengan Syamsuddin Muhammad (Rumi 2004: 12-13). Di dalam diri kedua orang itu, Rumi menemukan cermin yang memantulkan cahaya Ilahi dengan sempurna. Berhadapan dengan kedua orang itu, Rumi menjadi Sang Pencinta. Di dalam sufisme, cinta adalah sesuatu yang bernilai universal dan ada dalam diri setiap manusia, apa pun agamanya, di mana pun ia berada. Cinta merupakan sumber dari hubungan 
antara Tuhan dan ciptaan-Nya, yakni manusia dan alam semesta. Dengan memiliki cinta, manusia dapat berupaya untuk menjadikan dirinya Manusia Sempurna (Insan Kamil) melalui jalan cinta.

Di dalam karya Schmitt, cinta yang ditawarkan oleh Chevalier kepada Don Juan adalah cinta yang berbeda. Cinta yang tidak berdasarkan kenikmatan fisik atau seksual, cinta yang tanpa pamrih dan cinta yang penuh pengorbanan. Cinta yang juga dirasakan oleh Don Juan ini bahkan dirasakan menjadi bukti keberadaan Tuhan. Don Juan yang ateis telah berubah. Chevalier telah membukakan jalan baginya untuk lahir kembali menjadi pribadi baru, yang merasakan kerinduan mendalam pada sesuatu, dan yang ingin dia lakukan hanyalah mencintai. Don Juan menjadi Sang Pencinta. Berbekal cinta yang mulai tumbuh di dalam dirinya dan pengorbanan Chevalier, Don Juan bertekad untuk menempuh jalan baru walaupun ia sendiri belum tahu tujuannya. Ingin menjadi Manusia Sempurna? Atau Tuhankah yang dicari Don Juan?

\section{DAFTAR ACUAN}

Horville, Robert (1977), Dom Juan de Molière une dramaturgie de rupture. Paris: Larousse. Molière (1935), Dom Juan ou Le Festin de Pierre. Paris: Larousse.

Rumi, Jalaluddin (2004). Yang Mengenal Dirinya Yang Mengenal Tuhannya. Bandung: Pustaka Hidayah.

Scherer, Jacques (1967), Sur le Dom Juan de Molière. Paris: SEDES.

Schmitt, Eric-Emmanuel (1999), "La Nuit de Valognes », dalam Théâtre. Paris: Albin Michel. http://www.eric-emmanuel Schmitt.com (28 Juni 2005).

Ubersfeld, Anne (1978), Lire le théâtre. Paris: Editions Sociales. 